\title{
Carcinoid Heart Disease: From Pathophysiology to Treatment - 'Something in the Way It Moves'
}

\author{
Simona Grozinsky-Glasberga ${ }^{\text {a }}$ Ashley B. Grossman ${ }^{b}$ David J. Gross ${ }^{\text {a }}$ \\ ${ }^{a}$ Neuroendocrine Tumor Unit, Endocrinology and Metabolism Service, Department of Medicine, Hadassah-Hebrew \\ University Medical Center, Jerusalem, Israel; ${ }^{b}$ Oxford Centre for Diabetes, Endocrinology and Metabolism, Radcliffe \\ Department of Medicine, University of Oxford, Churchill Hospital, Oxford, UK
}

\section{Key Words}

Carcinoid $\cdot$ Neuroendocrine $\cdot$ Heart $\cdot$ Valve $\cdot$ Tricuspid .

Serotonin $\cdot 5$-Hydroxyindoleacetic acid

\begin{abstract}
Carcinoid heart disease (CHD) is a rare cardiac manifestation occurring in patients with advanced neuroendocrine tumours and the carcinoid syndrome, usually involving the right-sided heart valves and eventually leading to right heart failure. The pathophysiology of CHD is still obscure and believed to be multifactorial, as a variety of vasoactive substances secreted by the tumour appear to be involved. The management of patients with $\mathrm{CHD}$ is complex, as both the systemic malignant disease and the heart involvement have to be addressed. Timely diagnosis and early surgical treatment in appropriately selected patients are of outmost importance, as CHD is associated with increased morbidity and mortality. Valve replacement surgery alleviates right heart failure and may also contribute to improved survival. In the present study we have comprehensively reviewed the existing literature to date, mainly focusing on the pathophysiology of CHD. Other aspects of CHD (such as the clinical presentation, diagnostic tools and therapeutic approach) are addressed in brief.

(c) 2015 S. Karger AG, Basel
\end{abstract}

() 2015 S. Karger AG, Basel

0028-3835/15/1014-0263\$39.50/0

\section{Introduction}

Neuroendocrine tumours (NETs), previously known as carcinoid tumours, are rare malignancies, with an incidence of 5.1/100,000/year, occurring mainly in the gastrointestinal tract $(67.5 \%)$ followed by the bronchopulmonary system $(25.3 \%)[1,2]$. However, they may develop everywhere in the body, either from various endocrine glands (the pituitary, the parathyroid or the adrenal medulla), from endocrine cells within secretory organs (thyroid C-cell and pancreas islets of Langerhans), but mainly from neuroendocrine cells distributed between exocrine cells throughout the digestive and respiratory tracts $[1,2]$. NETs may present with a diversity of morphological and behavioural characteristics, the vast majority being relatively slow-growing tumours (well-differentiated NETs), whereas some of them may present with a highly malignant phenotype (poorly differentiated neuroendocrine carcinoma). NETs may be 'functioning' or 'nonfunctioning' based on the presence or the absence of clinical symptoms of hormonal hypersecretion; however, non-functioning tumours may well show immunohistochemical positivity for hormones, neuropeptides or neurotransmitters, and this distinction may to some extent be artificial $[3,4]$.

NETs may secrete as many as 40 secretory products (vasoactive substances), the most prominent being 5-hy-

\section{KARGER 125}

E-Mail karger@karger.com www.karger.com/nen 
droxytryptamine (5-HT, serotonin) but also tachykinins, kallikrein or prostaglandins. These tumour products are usually inactivated by the liver [5-9]. In approximately $30-40 \%$ of NET patients, when hepatic spread from a primary gastrointestinal NET results in hormonally active tumour products exceeding the hepatic capacity for degradation, the classical carcinoid syndrome (CS) ensues [10-12]. Rarely, CS may appear without pre-existing liver metastases in patients with extensive retroperitoneal lymph node metastases and drainage bypassing the liver via the thoracic duct and retroperitoneal venous collaterals or when the tumour products drain directly into the systemic circulation such as in the rare case of ovarian NETs $[13,14]$. The classical (typical) CS is usually characterized by cutaneous flushing, gut hypermotility with diarrhoea and bronchospasm with wheezing and shortness of breath [15]. The atypical CS is rare, mainly occurring in the context of lung NETs. It is characterized by extended episodes of flushing, headache, shortness of breath and, in rare cases, lacrimation [16].

Carcinoid heart disease (CHD, Hedinger syndrome), a rare and unique manifestation, has been described in up to $60 \%$ of patients with both NETs and CS, typically inducing abnormalities of the right side of the heart [17]. CHD occurs most frequently in patients with NETs originating in the small bowel (72\%) followed by NETs of the lung, large bowel, pancreas, appendix, or ovarian origin. However, in approximately $18 \%$ of cases the primary tumour site cannot be determined [18]. A slight male preponderance $(\sim 60 \%)$ has been reported, with a mean age at diagnosis of 56-63 years.

CHD is diagnosed approximately 1.5 years after the initial diagnosis of NET and CS [19]. However, diagnosis at the earliest stage possible is essential as the development of right ventricular dysfunction portends a poor prognosis and represents a major cause of morbidity and mortality, with death as a result of cardiac decompensation in as high as $43 \%$ in untreated patients [20-23].

In the present study we have comprehensively reviewed the existing literature to date, mainly focusing on the pathophysiology of CHD. Other aspects of CHD (such as the clinical presentation, diagnostic tools and therapeutic approach) are addressed in brief.

\section{Pathophysiology}

The precise mechanisms responsible for the development of CHD remain obscure. The disease is thought to be multifactorial and mediated by a variety of vasoactive substances secreted by the tumour, including 5-HT (serotonin), prostaglandins, histamine, bradykinin, and other substances with fibroblast proliferative properties such as tachykinins (substance $P$, neurokinin $A$, neuropeptide $\mathrm{K}$ ) or transforming growth factor- $\beta$ (TGF- $\beta$ ), which finally lead to the deposition of plaques on the endocardial surfaces of valve leaflets, subvalvular apparatus (chordae and papillary muscles) and cardiac chambers and occasionally within the intima of the pulmonary arteries and the aorta. These plaque-like deposits are composed of myofibroblasts, smooth muscle cells, extracellular matrix (ECM) components (collagen and myxoid ground substance), and an endocardial cell layer [17, 24]. These deposits usually involve primarily the right side of the heart (in $~ 90 \%$ of cases), specifically the downstream side of the valve leaflets, i.e. the ventricular aspect of the tricuspid valve and the pulmonary arterial side of the pulmonary valve [5]. Simultaneous involvement of both the tricuspid and pulmonary valves strongly suggests $\mathrm{CHD}$ as the likely diagnosis, demonstrating a pathognomonic appearance. In the pulmonary valve the plaques are deposited on the leaflets, leading to the adherence of pulmonic leaflets to the pulmonary arterial endocardium and resulting in a mixture of valvular stenosis and regurgitation, whereas in the tricuspid valve regurgitation tends to be predominant as the plaques involve mainly the subvalvular apparatus $[18,24,25]$. Compared with the right side of the heart, the left-sided valves are rarely affected because of the pulmonary metabolism and deactivation of the hormonal substances [18]. However, left-sided involvement is more frequent in patients with patent foramen ovale (76-88\%) [26], which appears to be more common in patients with CS and CHD compared with the general population (up to $41 \%$ in patients with CS and up to $59 \%$ in those with CHD) [27].

The complex mechanism of cardiac plaque formation in CHD is considered to be multifactorial. Initial animal studies postulated that the variety of vasoactive substances secreted by the NET may exert paraneoplastic effects [28]. For example, bradykinin has been reported to induce endocardial injury, the resulting fibrosis representing a healing response of the endocardium. Moreover, tachykinin was described as a pro-proliferative agent for the endocardial fibroblasts, thereby inducing plaque formation [29].

Nowadays, there is a strong body of evidence implying that serotonin plays a major role in stimulating fibroblast growth and fibrogenesis [28]. It is well known that urinary 5-hydroxyindoleacetic acid (5-HIAA), the serotonin metabolite which reflects the amount of serotonin pro- 
duction, is significantly higher in patients with $\mathrm{CHD}$ compared with those without cardiac involvement [17, 30].

\section{Serotonin and Serotonin Receptors}

Serotonin (5-HT), synthesized from the amino acid tryptophan subsequent to hydroxylation and decarboxylation, is a well-known neurotransmitter found in neurons located along the raphe nuclei of the brainstem. Outside the central nervous system, serotonin is produced mainly by the enterochromaffin (or Kulchitsky) cells, dispersed throughout the gastrointestinal and bronchopulmonary system, being involved in cell motility, fluid secretion and regional blood circulation $[31,32]$.

Serotonin actions are mediated by interaction with seven serotonin receptor classes [33] located on the cell membrane of neurons and of many other cells in the body $[34,35]$. There are six types of serotonin $G$ protein-coupled receptors (5-HTR 1, 2, 4, 5, 6, 7); the seventh type of 5 -HTR, $5-\mathrm{HTR}_{3}$, is unique as it is a ligand-gated ion channel $[36,37]$. The $5-\mathrm{HT}_{2}$ receptors are among the most frequently targeted $[34,38]$. Specifically, $5-\mathrm{HT}_{2 \mathrm{~B}}$ receptors have been found to be present, particularly, in the cardiovascular system, gastrointestinal tract, bone, and CNS, with similar tissue distribution and pharmacological properties in both rodents and humans, thereby facilitating extrapolation of rodent studies to humans [3942].

There is an emerging body of evidence for the key role of serotonin in the development of $\mathrm{CHD}$, as follows:

1 Serotoninergic drugs used in the treatment of obesity, migraine and Parkinson's disease have been demonstrated to cause valvular fibrosis [10] similar to that seen in patients with CHD. The current hypotheses came about as a result of inadvertent targeting of the $5-\mathrm{HT}_{2 \mathrm{~B}}$ receptors with the 'fen-phen' anorexigen combination [43]. Fenfluramine, but mainly its active metabolite norfenfluramine, are known to be potent agonists of the $5-\mathrm{HT}_{2 \mathrm{~B}}$ receptors, which are abundantly expressed on human cardiac valves. It is believed that the repeated stimulation of $5-\mathrm{HT}_{2 \mathrm{~B}}$ receptors induces uncontrolled valve cell division $[41,44]$. Moreover, the administration of different dopamine agonists in patients with Parkinson's disease (such as pergolide or cabergoline) has also been associated with the occurrence of similar valvular changes $[45,46]$.

2 Studies on cell cultures have shown that serotonin has mitogenic effects on fibroblasts [47], smooth muscle cells [48], osteoblasts $[49,50]$, renal mesangial cells [51], and endothelial cells [52].

Carcinoid Heart Disease
3 Preliminary animal studies using Sprague-Dawley rats and cynomolgus monkeys demonstrated that longterm exposure to high levels of serotonin induces morphological (shortened and thickened aortic cusps and carcinoid like plaques made of myofibroblasts within an ECM of collagen ground substance) as well as echocardiographic changes similar to those seen in human CHD [53-55]. It has been demonstrated that the overexpression of $5-\mathrm{HT}_{2 \mathrm{~B}}$ receptors in hearts of transgenic mice resulted in cardiac hypertrophy and decreased ventricular function due to enhanced ECM deposition and remodelling [56], whereas genetic deletion of $5-\mathrm{HT}_{2 \mathrm{~B}}$ receptors has been shown to lead to ventricular dilatation and incomplete cardiac development [57].

The signal transduction effects induced by the $5-\mathrm{HT}_{2 \mathrm{~B}}$ receptor activation in different cells and tissues are complex and may include the following:

1 Stimulation of phospholipase $\mathrm{C}$ and phospholipase A2 $[58,59]$.

2 Stimulation of nitric oxide synthase [60].

3 Mitosis initiation [41,61], together with the increase in the secretion of inflammatory cytokines such as TNF- $\alpha$ and ECM components $[62,63]$.

4 Activation of MAPK (mitogen-activated protein kinase) [64].

5 Phosphorylation of the cytoplasmic tyrosine kinase Src and activation of ERK (extracellular-regulated kinase) $[61,65]$.

6 Phosphorylation of retinoblastoma protein ( $\mathrm{Rb}-\mathrm{P})$ and cell cycle progression [66].

7 Overexpression of TGF- $\beta 1$ : the $5-\mathrm{HT}_{2 \mathrm{~B}}$ receptor works in concert with the angiotensin II type 1 receptor (AT1R) to mediate hypertrophic signalling in cardiac fibroblasts [63]. The agonist signalling of these receptors has been shown to induce an increase in the synthesis and upregulation of the cytokine TGF- $\beta 1[67$, 68], known to stimulate fibroblasts to produce ECM proteins; TGF- $\beta 1$ is overexpressed in CHD lesions and seems to be a major mediator in the tissue changes related to the valvular disease $[69,70]$ (fig. 1).

Despite the growing body of evidence showing the major involvement of serotonin in the development of CHD, more than $50 \%$ of patients with elevated circulating serotonin levels do not develop CHD [9], implying therefore that other biochemical mediators are also significant; activin A [13] and connective tissue growth factor (CTGF) [71] have been associated with the development of the disease in these patients. Activin A, a cytokine member of the TGF- $\beta$ superfamily with fibrogenic properties, was found to be expressed in the fibrotic plaques of CHD le- 


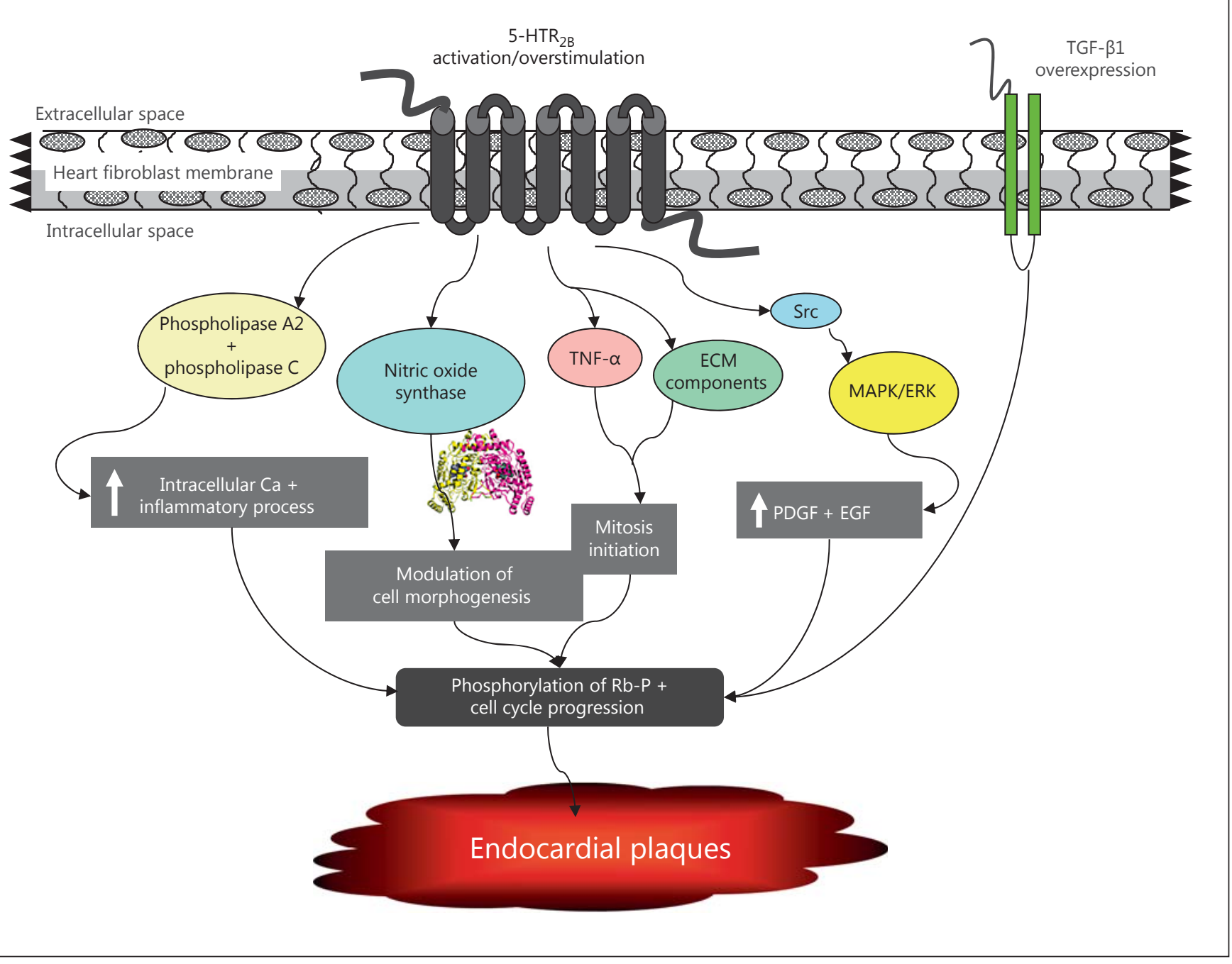

Fig. 1. The signal transduction effects induced by the $5-\mathrm{HT}_{2 \mathrm{~B}}$ receptor activation. $\mathrm{PDGF}=$ Platelet-derived growth factor; $\mathrm{EGF}=$ epidermal growth factor; $\mathrm{Rb}-\mathrm{P}=$ phosphorylated of retinoblastoma protein.

sions [72]. Intestinal NETs overexpress CTGF and TGF- $\beta 1$ mRNA and synthesize CTGF and TGF- $\beta 1$ proteins, which act in concert to drive the overproduction of collagen, contributing to the initiation and maintenance of the fibrotic process $[73,74]$.

\section{Clinical Features of CHD Patients}

Early in the course of the disease the clinical manifestations of CHD are often subtle, as tricuspid and pulmonary valve disease of various degrees may be well tolerated for long periods of time and difficult to detect be- cause of the low pressure in the pulmonary circulation $[19,25]$. Early symptoms usually include fatigue and dyspnoea, mainly on exertion. Then, in parallel with tumour progression and the increased levels of serotonin, progressive right-sided heart failure with worsening dyspnoea, anasarca and cardiac cachexia eventually occurs. However, in a substantial proportion of patients with cardiac involvement no symptoms or signs suggesting $\mathrm{CHD}$ are found; in these patients a high degree of awareness is necessary to establish a timely diagnosis [75].

On physical examination, elevated jugular venous pressure and a palpable right ventricular impulse may be found. Murmurs of tricuspid and pulmonary valve regur- 
Fig. 2. Transthoracic echocardiogram of the tricuspid valve in CHD. RA = Right atrium; RV = right ventricle. $\mathbf{a}$ Right ventricular inflow view demonstrating thickened and retracted anterior and posterior leaflets of the tricuspid valve, resulting in malcoaptation at end-systole (arrows). b Colour flow Doppler image showing severe tricuspid regurgitation as a result of malcoaptation.
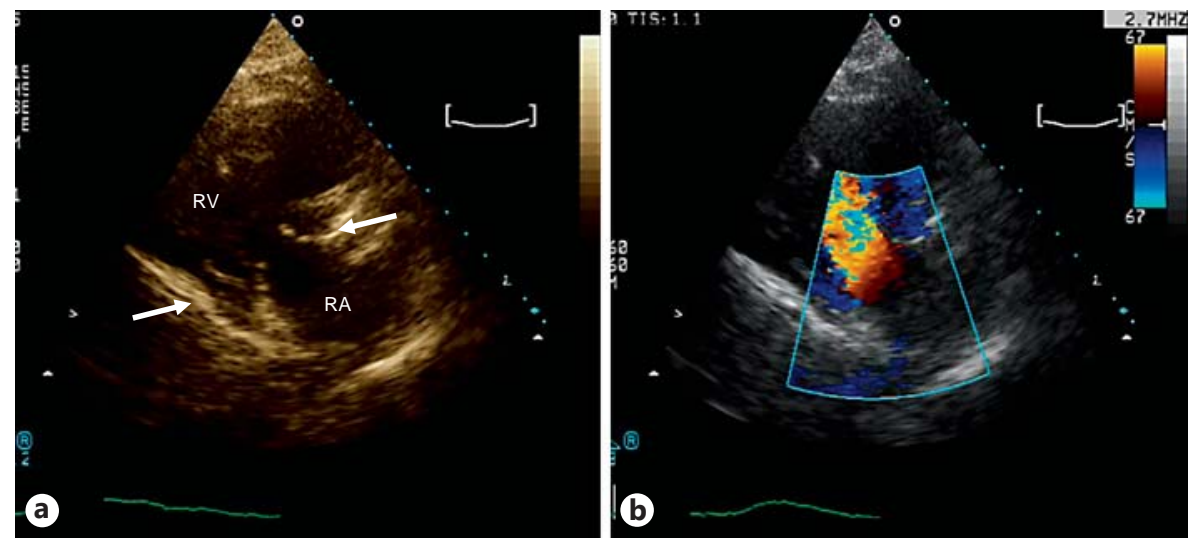

gitation are frequent on heart auscultation, whereas a systolic murmur of pulmonary stenosis or a diastolic murmur of tricuspid stenosis is rarely described. As the valve disease progresses, peripheral oedema, ascites and pulsatile hepatomegaly develop [21, 75]. Clinical assessment, including New York Heart Association (NYHA) classification and physical examination, to identify signs of valvular disease is rarely sufficient to make the diagnosis [76].

\section{Biochemical Evaluation of Patients with CHD}

- NET patients with CHD have been shown to have 2- to 4 -fold higher values of serum serotonin, platelet serotonin and urinary 5-HIAA levels than those without CHD [30]. Elevated 5-HIAA urinary levels have been correlated with an increased risk of CHD progression, as well as with worsening of the echocardiographic findings [77-79].

- Chromogranin A has also been suggested as a sensitive marker for patients with NETs and CHD [80].

- N-terminal pro-brain natriuretic peptide (NT-proBNP) belongs to a neurohormone family released by the atria and ventricles in response to the increase in wall stress in response to both volume and pressure overload and may act as an antifibrotic agent in the myocardium [81, 82]. To date, NT-proBNP has been considered extremely useful in the evaluation of CHD severity and prognosis, as its median levels appear to be significantly higher in patients with CHD than in those without [83]. Moreover, NT-proBNP has a high sensitivity and specificity ( 87 and $80 \%$, respectively) in predicting CHD in NETs and correlates with patient survival [80]. Therefore, this marker is highly recom- mended by the UK and Ireland NET Society (UKI NETS) guidelines as a screening tool for CHD in patients with intestinal NETs, with or without hepatic metastases, and in all patients with CS $[83,84]$.

- Plasma activin A levels were reported to be significantly higher in NET patients with CHD compared with those without. Activin A was defined as an independent predictor for the presence of CHD, with $87 \%$ sensitivity and $57 \%$ specificity for detecting $\mathrm{CHD}$ at plasma levels of $\geq 0.34 \mathrm{ng} / \mathrm{ml}$ [72]. As plasma activin A levels were increased in both the early and the advanced stages of $\mathrm{CHD}$, it was suggested that its assessment may be indicative of early CHD compared with elevated circulating levels of neuropeptide K, substance $\mathrm{P}$ and atrial natriuretic peptide, which were considered as markers of advanced CHD in earlier studies $[20,85]$. Moreover, in contrast with NT-pro$\mathrm{BNP}$, increased activin A levels were also found in CHD patients without right heart dilatation [72].

- Elevated CTGF levels were reported to represent an independent predictor factor of reduced right ventricular function, with $88 \%$ sensitivity and $69 \%$ specificity in NET patients with CHD [86].

\section{Imaging Modalities for CHD}

The principal imaging modality used in the assessment of CHD is echocardiography (fig. 2). On a 2-dimensional transthoracic echocardiogram, the affected tricuspid valve typically appears thickened. Then, in parallel with disease progression, the leaflets become fixed and retracted in a half-open position, resulting in regurgitation with some degree of stenosis $[87,88]$. Colour flow Doppler may help further characterize the degree of tricuspid regurgitation. 


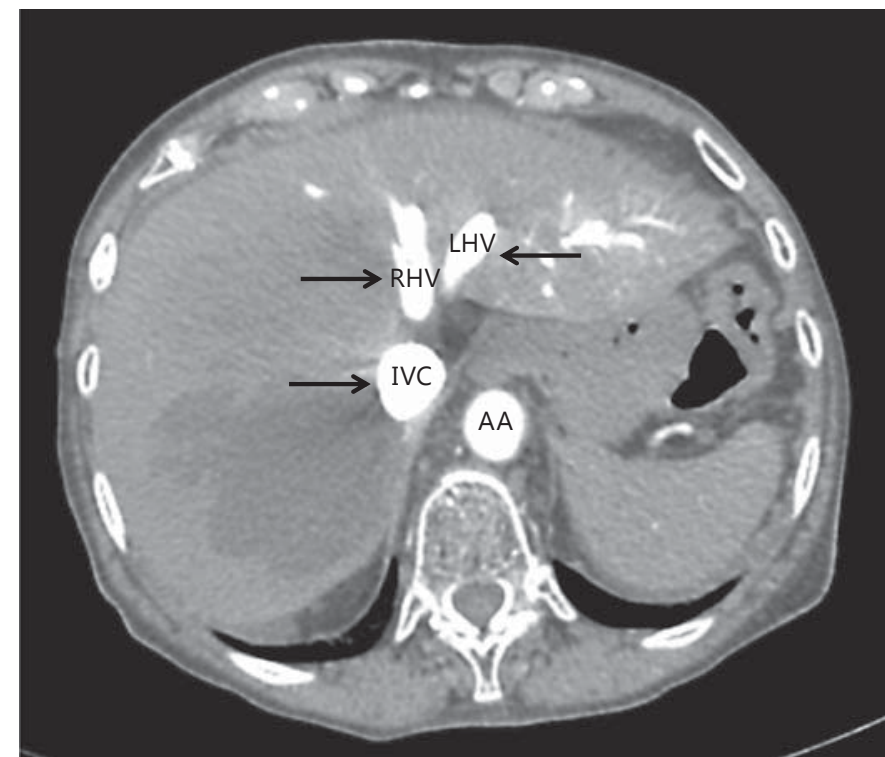

Fig. 3. High-resolution $\mathrm{CT}$ of the abdomen (axial image) in a patient with NET, CS and CHD. IVC = Inferior vena cava; RHV = right hepatic vein; $\mathrm{LHV}=$ left hepatic vein; $\mathrm{AA}=$ abdominal aorta. Reflux of contrast material into inferior vena cava and hepatic veins during arterial phase of CT study can be seen (arrows), which is highly indicative of severe tricuspid valve regurgitation and right heart failure.

Involvement of the pulmonic valve may also lead to a thickened appearance with reduced movement. As a consequence of valvular disease, the right-sided cardiac chambers may become progressively dilated and hypokinetic: 3-dimensional transthoracic echocardiography/transoesophageal echocardiography provides detailed anatomic information, particularly for the tricuspid and pulmonary valves, enhancing the ability to detect the involvement of chordae and papillary muscles [87]. Several echocardiographic scoring systems have been developed to assess the progression of CHD. However, the clinical relevance of these scoring systems is uncertain, and it has been shown that they are comparable in their discriminatory ability for the detection of cardiac involvement and correlate with the biomarkers of CHD [89].

Other imaging modalities may be valuable in the assessment of disease severity. Cardiac MRI [90, 91] overcomes the issue of suboptimal visualization of the rightsided heart valves and enables accurate quantification of regurgitant volumes and right ventricular ejection fraction, which is pivotal to the long-term management of the patients [75]. Occasionally, CHD is diagnosed by the radiologist on contrast-enhanced CT, where reflux of con- trast from the right atrium to the inferior vena cava and hepatic veins is noted (fig. 3). Positron emission tomography, using synthetic radiolabelled octreotide with radio-nuclide tracers such as ${ }^{68} \mathrm{Ga}$ and ${ }^{18} \mathrm{~F}$-dihydroxy-phenyl-alanine, can also identify cardiac metastases [87, 92].

Consensus European Neuroendocrine Tumor Society (ENETS) guidelines recommended that annual echocardiography be mandatory as part of the routine surveillance of CHD patients [93-95]. Importantly, in the early stages of the disease, subtle thickening of the tricuspid valve leaflets and subvalvular apparatus with mild tricuspid regurgitation may appear as a non-specific finding. These patients should be therefore screened regularly, and comparisons should be made with previous echocardiograms to assess valvular disease progression. Echocardiography should be performed by an experienced echo sonographer with considerable personal experience (at least 200 examinations/year) [96].

\section{Stepwise Therapeutic Approach in Patients with CHD}

Patients with the rare diagnosis of CHD developing in the context of a metastatic NET and the CS should be treated in specialized centres by a multidisciplinary team including endocrinologists, oncologists, cardiologists, pathologists, and surgeons with experience in the treatment of this complex condition [75]. Without a timely intervention, NET patients with CHD will eventually develop progressive right heart failure in parallel with a significant decrease in their life expectancy compared with those NET patients without CHD [18] (fig. 4).

\section{Medical Therapy and Tumour Debulking}

Treatment with somatostatin analogues is based on NET cell ability to express specific somatostatin receptors on their surface membrane, a characteristic being of great value for both tumour imaging and staging as well as for the treatment of these tumours [97]. Treatment with somatostatin analogues and/or tumour debulking techniques (hepatic artery embolization, palliative hepatic cytoreductive surgery, etc.) may improve the symptoms of the CS $[98,99]$ as well as the negative haemodynamic impact of tumour vasoactive agents on $\mathrm{CHD}$ and on the development of heart failure [100]. However, to date, there is no current evidence suggesting that these interventions are beneficial in terms of CHD progression [77]. Moreover, bacterial endocarditis prophylaxis is not indicated in patients with CHD [101]. 


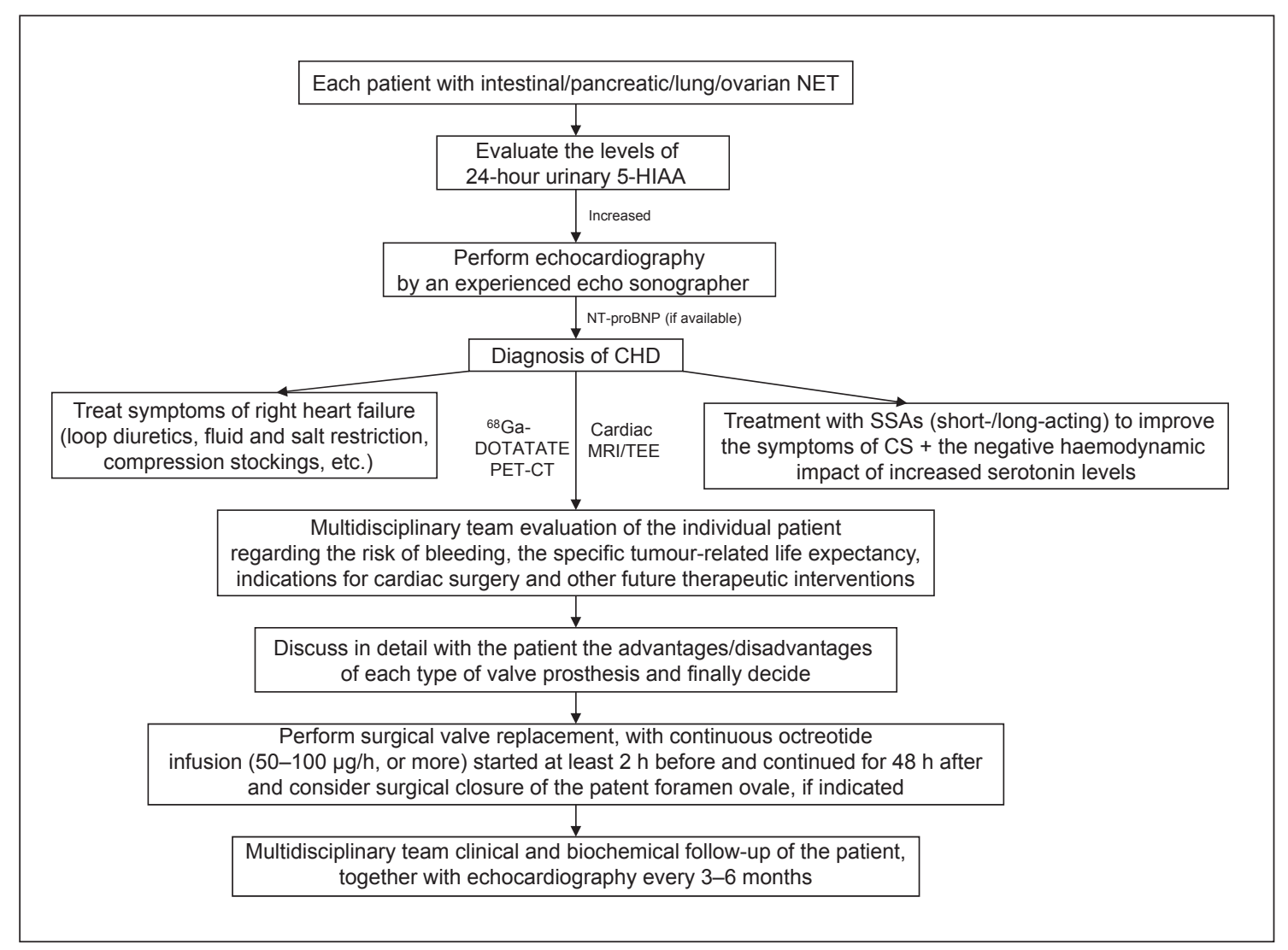

Fig. 4. Stepwise therapeutic approach in patients with CHD. ${ }^{68} \mathrm{Ga}$-DOTATATE PET-CT = Positron emission tomography using synthetic radiolabeled octreotide with ${ }^{68} \mathrm{Ga}$; TEE = transesophageal echocardiography; SSAs = somatostatin analogues.

In the perioperative setting, continuous somatostatin analogue (octreotide) infusion ( $50-100 \mu \mathrm{g} / \mathrm{h}$, or more) is of outmost importance [102]; it should be started at least $2 \mathrm{~h}$ before surgery and continued for $48 \mathrm{~h}$ afterwards, with a slow tapering down before treatment discontinuation [103]. The octreotide infusion is aimed at reducing serotonin release, optimizing surgical outcome by reducing perioperative complications such as hypotension, carcinoid crisis and death [104]. Antihistamines may also be used before surgery to prevent flushing and bronchospasm, whereas corticosteroids can be used to reduce bradykinin production [17]. In the perioperative setting, minimizing the use of specific drugs known to precipitate vasoactive products released by the tumour (such as opioids, the neuromuscular relaxant atracurium, dopamine, or adrenaline/epinephrine) is strongly advised to reduce the risk of carcinoid crisis [105].

Recently, telotristat etiprate, a novel serotonin synthesis inhibitor, has been reported as being highly effective for alleviating diarrhoea in patients with CS inadequately controlled by octreotide alone. As a biochemical response ( $\geq 50 \%$ reduction or normalization in $24 \mathrm{~h}$ of urinary 5 -HIAA levels) has been reported in most of the patients, this new drug may be promising for patients with $\mathrm{CHD}$ with intractably elevated levels of serotonin [106].

The use of loop diuretics, together with fluid and salt restriction and compression stockings, may initially relieve the symptoms of right heart failure. However, in advanced right ventricular failure these measures become ineffective and even deleterious due to the depletion of intravascular volume, further reducing of the cardiac output [17].

\section{Balloon Valvuloplasty}

In patients not suitable for cardiac valve surgery, balloon valvuloplasty has been used to treat stenotic pulmonary or tricuspid valves [107]. Although some short-lasting functional and haemodynamic benefit has been re- 
ported, the rapid relapse of valvular disease renders the use of this technique of limited value [108].

\section{Surgical Valve Replacement in CHD}

Patients with CHD usually die as a result of severe tricuspid regurgitation [109] rather than carcinomatosis. Whereas previously undertaken only in severely symptomatic patients with advanced cardiac disease, surgical valve replacement is now performed earlier because of the increased perioperative mortality in patients with severe heart failure and improvements in cardiac surgery [23, 28]. As valvular surgery offers definitive therapy for CHD-related symptoms, marked symptomatic improvement usually occurs after valve replacement $[109,110]$. The reports on median survival after cardiac valve replacement vary between 6 and 11 years [19]. The improved survival of patients with $\mathrm{CHD}$ in recent years may reflect the increasing surgical expertise in this field and better perioperative management of the patient with octreotide [75].

The choice of the type of valve prosthesis (biological vs. mechanical) is controversial as the literature is limited to small, retrospective series or case reports [111]. On the one hand, biological prosthetic valve degeneration with valve allograft failure has been reported to occur as early as 3 months after implantation, being the result of intractable high levels of NET vasoactive products inducing carcinoid plaque reformation [112-114]; on the other hand, the use of mechanical prosthesis requires life-time anticoagulation in these patients who have an already increased risk of bleeding due to hepatic dysfunction, together with an increased risk of valve thrombosis [115, 116].

The decision on the type of prosthesis is complex and should be individually tailored based on the individual patient risk of bleeding, the specific tumour-related life expectancy and possible future therapeutic interventions. The advantages and disadvantages of both valve types should be discussed in detail with the patient as part of the decision-making process. A recent overview on the outcome of $\mathrm{CHD}$ patients following valvular surgery suggested that surgical intervention can lead to improved prognosis and should therefore be considered for symptomatic palliation in carefully selected individuals [117]. Moreover, a recent paper aimed at identifying outcomes, risks and complications related to valve surgery for $\mathrm{CHD}$ patients suggested that surgical valvular replacement presented a higher risk compared with most other forms of valvular surgery. However, in patients surviving the operation, a significant improvement in functional class could be observed, whereas most long-term complications were related to the tumour itself and not to the cardiac procedure [118].

In the rare patients with left-heart valvular involvement due to interatrial shunts via a patent foramen ovale, surgical closure of the patent foramen ovale is advised, inducing a dramatic relief of symptoms [119].

\section{Conclusions}

CHD is a rare and severe complication of advanced NETs and is associated with increased morbidity and mortality. The biological basis for the development of $\mathrm{CHD}$ remains obscure, despite the emerging evidence indicating that serotonin plays a main role in the pathological process of valve destruction and dysfunction. Early recognition and surgical intervention, before advanced heart failure has occurred, may improve the outcome of these patients. A better understanding of the molecular mechanisms underlying the progression of fibrosis in CHD may lead to the development of appropriate targets for targeted molecular therapy. Finally, the management of patients with $\mathrm{CHD}$ is extremely complex and requires a multidisciplinary approach involving specialists with broad experience in the field.

\section{Disclosure Statement}

The authors have no conflicts of interest to declare.

References

Neuroendocrinology 2015;101:263-273 DOI: $10.1159 / 000381930$
1 Rindi G, Villanacci V, Ubiali A: Biological and molecular aspects of gastroenteropancreatic neuroendocrine tumors. Digestion 2000; 62(suppl 1):19-26.

2 Solcia E, Rindi G, Paolotti D, La Rosa S, Capella C, Fiocca R: Clinicopathological profile as a basis for classification of the endocrine tumours of the gastroenteropancreatic tract. Ann Oncol 1999;10(suppl 2):S9-S15.

3 Raja SG, Bhattacharyya S, Davar J, Dreyfus GD: Surgery for carcinoid heart disease: current outcomes, concerns and controversies. Future Cardiol 2010;6:647-655.

4 Oberg K: Neuroendocrine tumors of the gastrointestinal tract: recent advances in molecular genetics, diagnosis, and treatment. Curr Opin Oncol 2005; 17:386-391.

5 Modlin IM, Kidd M, Latich I, Zikusoka MN, Shapiro MD: Current status of gastrointestinal carcinoids. Gastroenterology 2005;128: 1717-1751. 
6 Oates JA: The carcinoid syndrome. N Engl J Med 1986;315:702-704.

7 Vinik AI, McLeod MK, Fig. LM, Shapiro B, Lloyd RV, Cho K: Clinical features, diagnosis, and localization of carcinoid tumors and their management. Gastroenterol Clin North Am 1989;18:865-896.

8 Makridis C, Theodorsson E, Akerstrom G, Oberg K, Knutson L: Increased intestinal non-substance $\mathrm{P}$ tachykinin concentrations in malignant midgut carcinoid disease. J Gastroenterol Hepatol 1999; 14:500-507.

9 Cunningham JL, Janson ET, Agarwal S, Grimelius L, Stridsberg M: Tachykinins in endocrine tumors and the carcinoid syndrome. Eur J Endocrinol 2008;159:275-282.

10 Feldman JM: Carcinoid tumors and syndrome. Semin Oncol 1987;14:237-246.

11 Roberts LJ 2nd, Marney SR Jr, Oates JA: Blockade of the flush associated with metastatic gastric carcinoid by combined histamine $\mathrm{H} 1$ and $\mathrm{H} 2$ receptor antagonists. Evidence for an important role of $\mathrm{H} 2$ receptors in human vasculature. N Engl J Med 1979; 300:236-238.

12 Kvols LK: Metastatic carcinoid tumors and the malignant carcinoid syndrome. Ann NY Acad Sci 1994;733:464-470.

13 Morin LJ, Zuerner RT: Retroperitoneal fibrosis and carcinoid tumor. JAMA 1971;216: 1647-1648.

14 Ansell JK, Stebbings WS: Carcinoid syndrome due to a primary ovarian carcinoid tumour. J R Soc Med 1993;86:668.

15 Soga J: Carcinoids and their variant endocrinomas. An analysis of 11,842 reported cases. J Exp Clin Cancer Res 2003;22:517-530.

16 Tomassetti P, Migliori M, Lalli S, Campana D, Tomassetti V, Corinaldesi R: Epidemiology, clinical features and diagnosis of gastroenteropancreatic endocrine tumours. Ann Oncol 2001;12(suppl 2):S95-S99.

17 Fox DJ, Khattar RS: Carcinoid heart disease: presentation, diagnosis, and management. Heart 2004;90:1224-1228.

18 Pellikka PA, Tajik AJ, Khandheria BK, Seward JB, Callahan JA, Pitot HC, Kvols LK: Carcinoid heart disease. Clinical and echocardiographic spectrum in 74 patients. Circulation 1993;87:1188-1196.

19 Moller JE, Pellikka PA, Bernheim AM, Schaff HV, Rubin J, Connolly HM: Prognosis of carcinoid heart disease: analysis of 200 cases over two decades. Circulation 2005; 112: 3320-3327.

20 Lundin L, Norheim I, Landelius J, Oberg K, Theodorsson-Norheim E: Carcinoid heart disease: relationship of circulating vasoactive substances to ultrasound-detectable cardiac abnormalities. Circulation 1988;77:264-269.

21 Ross EM, Roberts WC: The carcinoid syndrome: comparison of 21 necropsy subjects with carcinoid heart disease to 15 necropsy subjects without carcinoid heart disease. Am J Med 1985;79:339-354.

22 Moyssakis IE, Rallidis LS, Guida GF, Nihoyannopoulos PI: Incidence and evolution of carcinoid syndrome in the heart. J Heart Valve Dis 1997;6:625-630.

23 Connolly HM, Schaff HV, Mullany CJ, Abel MD, Pellikka PA: Carcinoid heart disease: impact of pulmonary valve replacement in right ventricular function and remodeling. Circulation 2002;106:I51-I56.

24 Bernheim AM, Connolly HM, Hobday TJ Abel MD, Pellikka PA: Carcinoid heart disease. Prog Cardiovasc Dis 2007;49:439-451.

25 Patel C, Mathur M, Escarcega RO, Bove AA: Carcinoid heart disease: current understanding and future directions. Am Heart J 2014; 167:789-795

26 Mansencal N, Mitry E, Forissier JF, Martin F, Redheuil A, Lepere C, Farcot JC, Joseph T, Lacombe P, Rougier P, Dubourg O: Assessment of patent foramen ovale in carcinoid heart disease. Am Heart J 2006;151:1129.e1121e1126.

27 Mansencal N, Mitry E, Pilliere R, Lepere C, Gerardin B, Petit J, Gandjbakhch I, Rougier P, Dubourg O: Prevalence of patent foramen ovale and usefulness of percutaneous closure device in carcinoid heart disease. Am J Cardiol 2008;101:1035-1038.

28 Gustafsson BI, Hauso O, Drozdov I, Kidd M, Modlin IM: Carcinoid heart disease. Int J Cardiol 2008;129:318-324.

29 Oates JA, Melmon K, Sjoerdsma A, Gillespie L, Mason DT: Release of a kinin peptide in the carcinoid syndrome. Lancet 1964;1:514-517.

30 Zuetenhorst JM, Bonfrer JM, Korse CM, Bakker R, van Tinteren H, Taal BG: Carcinoid heart disease: the role of urinary 5-hydroxyindoleacetic acid excretion and plasma levels of atrial natriuretic peptide, transforming growth factor- $\beta$ and fibroblast growth factor. Cancer 2003;97:1609-1615.

31 Gershon MD: Review article: roles played by 5-hydroxytryptamine in the physiology of the bowel. Aliment Pharmacol Ther 1999; 13(suppl 2):15-30.

32 Erspamer V, Asero B: Identification of enteramine, the specific hormone of the enterochromaffin cell system, as 5-hydroxytryptamine. Nature 1952;169:800-801.

33 Hoyer D, Hannon JP, Martin GR: Molecular, pharmacological and functional diversity of 5-HT receptors. Pharmacol Biochem Behav 2002;71:533-554.

34 Roth BL: Irving Page Lecture: $5-\mathrm{HT}_{2 \mathrm{~A}}$ serotonin receptor biology: interacting proteins, kinases and paradoxical regulation. Neuropharmacology 2011;61:348-354.

35 Berger M, Gray JA, Roth BL: The expanded biology of serotonin. Annu Rev Med 2009;60: 355-366.

36 Maricq AV, Peterson AS, Brake AJ, Myers RM, Julius D: Primary structure and functional expression of the $5 \mathrm{HT} 3$ receptor, a serotonin-gated ion channel. Science 1991;254: 432-437.

37 Roth BL, Willins DL, Kristiansen K, Kroeze WK: 5-Hydroxytryptamine ${ }_{2}$ family receptors (5-hydroxytryptamine ${ }_{2 \mathrm{~A}}, \quad$-hydroxytryptamine $_{2 \mathrm{~B}}$, 5-hydroxytryptamine ${ }_{2 \mathrm{C}}$ ): where structure meets function. Pharmacol Ther 1998;79:231-257.

38 Hutcheson JD, Setola V, Roth BL, Merryman WD: Serotonin receptors and heart valve disease - it was meant 2B. Pharmacol Ther 2011; 132:146-157.

39 Ullmer C, Schmuck K, Kalkman HO, Lubbert $\mathrm{H}$ : Expression of serotonin receptor mRNAs in blood vessels. FEBS Lett 1995;370:215-221.

40 Choi DS, Maroteaux L: Immunohistochemical localisation of the serotonin $5-\mathrm{HT}_{2 \mathrm{~B}}$ receptor in mouse gut, cardiovascular system, and brain. FEBS Lett 1996;391:45-51.

41 Fitzgerald LW, Burn TC, Brown BS, Patterson JP, Corjay MH, Valentine PA, Sun JH, Link JR, Abbaszade I, Hollis JM, Largent BL, Hartig PR, Hollis GF, Meunier PC, Robichaud AJ, Robertson DW: Possible role of valvular serotonin $5-\mathrm{HT}_{2 \mathrm{~B}}$ receptors in the cardiopathy associated with fenfluramine. Mol Pharmacol 2000;57:75-81.

42 Manivet P, Schneider B, Smith JC, Choi DS Maroteaux L, Kellermann O, Launay JM: The serotonin binding site of human and murine $5-\mathrm{HT}_{2 \mathrm{~B}}$ receptors: molecular modeling and site-directed mutagenesis. J Biol Chem 2002; 277:17170-17178.

43 Dahl CF, Allen MR, Urie PM, Hopkins PN Valvular regurgitation and surgery associated with fenfluramine use: an analysis of 5,743 individuals. BMC Med 2008;6:34.

44 Rothman RB, Baumann MH, Savage JE, Rauser L, McBride A, Hufeisen SJ, Roth BL: Evidence for possible involvement of $5-\mathrm{HT}_{2 \mathrm{~B}}$ receptors in the cardiac valvulopathy associated with fenfluramine and other serotonergic medications. Circulation 2000;102:28362841.

45 Antonini A, Poewe W: Fibrotic heart-valve reactions to dopamine agonist treatment in Parkinson's disease. Lancet Neurol 2007;6: 826-829.

46 Simonis G, Fuhrmann JT, Strasser RH: Metaanalysis of heart valve abnormalities in Parkinson's disease patients treated with dopamine agonists. Mov Disord 2007;22:1936-1942.

47 Seuwen K, Magnaldo I, Pouyssegur J: Serotonin stimulates DNA synthesis in fibroblasts acting through $5-\mathrm{HT}_{1 \mathrm{~B}}$ receptors coupled to a $\mathrm{G}_{\mathrm{i}}$-protein. Nature 1988;335:254-256.

48 Nemecek GM, Coughlin SR, Handley DA, Moskowitz MA: Stimulation of aortic smooth muscle cell mitogenesis by serotonin. Proc Natl Acad Sci USA 1986;83:674-678.

49 Bliziotes MM, Eshleman AJ, Zhang XW, Wiren KM: Neurotransmitter action in osteoblasts: expression of a functional system for serotonin receptor activation and reuptake. Bone 2001;29:477-486.

50 Westbroek I, van der Plas A, de Rooij KE, Klein-Nulend J, Nijweide PJ: Expression of serotonin receptors in bone. J Biol Chem 2001;276:28961-28968.

51 Takuwa N, Ganz M, Takuwa Y, Sterzel RB, Rasmussen H: Studies of the mitogenic effect of serotonin in rat renal mesangial cells. Am J Physiol 1989;257:F431-439. 
52 Pakala R, Willerson JT, Benedict CR: Mitogenic effect of serotonin on vascular endothelial cells. Circulation 1994;90:1919-1926.

53 Gustafsson BI, Tommeras K, Nordrum I, Loennechen JP, Brunsvik A, Solligard E, Fossmark R, Bakke I, Syversen U, Waldum H: Long-term serotonin administration induces heart valve disease in rats. Circulation 2005; 111:1517-1522.

54 Elangbam CS, Job LE, Zadrozny LM, Barton JC, Yoon LW, Gates LD, Slocum N: 5-Hydroxytryptamine (5HT)-induced valvulopathy: compositional valvular alterations are associated with $5 \mathrm{HT}_{2 \mathrm{~B}}$ receptor and $5 \mathrm{HT}$ transporter transcript changes in Sprague-Dawley rats. Exp Toxicol Pathol 2008;60:253-262.

55 Elangbam CS, Lightfoot RM, Yoon LW, Creech DR, Geske RS, Crumbley CW, Gates LD, Wall HG: 5-Hydroxytryptamine (5HT) receptors in the heart valves of cynomolgus monkeys and Sprague-Dawley rats. J Histochem Cytochem 2005;53:671-677.

56 Nebigil CG, Jaffre F, Messaddeq N, Hickel P, Monassier L, Launay JM, Maroteaux L: Overexpression of the serotonin $5-\mathrm{HT}_{2 \mathrm{~B}}$ receptor in heart leads to abnormal mitochondrial function and cardiac hypertrophy. Circulation 2003;107:3223-3229.

57 Nebigil CG, Choi DS, Dierich A, Hickel P, Le Meur M, Messaddeq N, Launay JM, Maroteaux L: Serotonin 2B receptor is required for heart development. Proc Natl Acad Sci USA 2000;97:9508-9513.

58 Kellermann O, Loric S, Maroteaux L, Launay JM: Sequential onset of three 5-HT receptors during the 5-hydroxytryptaminergic differentiation of the murine $1 \mathrm{C} 11$ cell line. Br J Pharmacol 1996;118:1161-1170.

59 Tournois C, Mutel V, Manivet P, Launay JM, Kellermann O: Cross-talk between 5-hydroxytryptamine receptors in a serotonergic cell line. Involvement of arachidonic acid metabolism. J Biol Chem 1998;273:17498-17503.

60 Manivet P, Mouillet-Richard S, Callebert J, Nebigil CG, Maroteaux L, Hosoda S, Kellermann O, Launay JM: PDZ-dependent activation of nitric-oxide synthases by the serotonin 2B receptor. J Biol Chem 2000;275:93249331.

61 Nebigil CG, Launay JM, Hickel P, Tournois C, Maroteaux L: 5-Hydroxytryptamine 2B receptor regulates cell-cycle progression: crosstalk with tyrosine kinase pathways. Proc Natl Acad Sci USA 2000;97:2591-2596.

62 Hafizi S, Taylor PM, Chester AH, Allen SP, Yacoub MH: Mitogenic and secretory responses of human valve interstitial cells to vasoactive agents. J Heart Valve Dis 2000;9:454458.

63 Jaffre F, Bonnin P, Callebert J, Debbabi H, Setola V, Doly S, Monassier L, Mettauer B, Blaxall BC, Launay JM, Maroteaux L: Serotonin and angiotensin receptors in cardiac fibroblasts coregulate adrenergic-dependent cardiac hypertrophy. Circ Res 2009;104:113123.
64 Launay JM, Birraux G, Bondoux D, Callebert J, Choi DS, Loric S, Maroteaux L: Ras involvement in signal transduction by the serotonin 5- $\mathrm{HT}_{2 \mathrm{~B}}$ receptor. J Biol Chem 1996;271:31413147.

65 Li H, Ung CY, Ma XH, Li BW, Low BC, Cao ZW, Chen YZ: Simulation of crosstalk between small GTPase RhoA and EGFR-ERK signaling pathway via MEKK1. Bioinformatics 2009;25:358-364.

66 Roth BL: Drugs and valvular heart disease. N Engl J Med 2007;356:6-9.

67 Jian B, Xu J, Connolly J, Savani RC, Narula N, Liang B, Levy RJ: Serotonin mechanisms in heart valve disease I: serotonin-induced upregulation of transforming growth factor- $\beta 1$ via G-protein signal transduction in aortic valve interstitial cells. Am J Pathol 2002;161: 2111-2121.

68 Rosenkranz S: TGF- $\beta 1$ and angiotensin networking in cardiac remodeling. Cardiovasc Res 2004;63:423-432.

69 Walker GA, Masters KS, Shah DN, Anseth KS, Leinwand LA: Valvular myofibroblast activation by transforming growth factor- $\beta$ : implications for pathological extracellular matrix remodeling in heart valve disease. Circ Res 2004;95:253-260.

70 Merryman WD, Huang HY, Schoen FJ, Sacks MS: The effects of cellular contraction on aortic valve leaflet flexural stiffness. J Biomech 2006;39:88-96.

71 Modlin IM, Shapiro MD, Kidd M: Carcinoid tumors and fibrosis: an association with no explanation. Am J Gastroenterol 2004;99: 2466-2478.

72 Bergestuen DS, Edvardsen T, Aakhus S, Ueland T, Oie E, Vatn M, Aukrust P, ThiisEvensen E: Activin A in carcinoid heart disease: a possible role in diagnosis and pathogenesis. Neuroendocrinology 2010;92:168177.

73 Kidd M, Modlin I, Shapiro M, Camp R, Mane S, Usinger W, Murren J: CTGF, intestinal stellate cells and carcinoid fibrogenesis. World J Gastroenterol 2007;13:5208-5216.

74 Kidd M, Modlin IM, Pfragner R, Eick GN, Champaneria MC, Chan AK, Camp L, Mane SM: Small bowel carcinoid (enterochromaffin cell) neoplasia exhibits transforming growth factor- $\beta 1$-mediated regulatory abnormalities including up-regulation of C-Myc and MTA1. Cancer 2007;109:2420-2431.

75 Dobson R, Burgess MI, Pritchard DM, Cuthbertson DJ: The clinical presentation and management of carcinoid heart disease. Int J Cardiol 2014;173:29-32.

76 Bhattacharyya S, Toumpanakis C, Caplin ME, Davar J: Analysis of 150 patients with carcinoid syndrome seen in a single year at one institution in the first decade of the twentyfirst century. Am J Cardiol 2008; 101:378-381.

77 Moller JE, Connolly HM, Rubin J, Seward JB, Modesto K, Pellikka PA: Factors associated with progression of carcinoid heart disease. N Engl J Med 2003;348:1005-1015.
78 Bhattacharyya S, Toumpanakis C, Chilkunda D, Caplin ME, Davar J: Risk factors for the development and progression of carcinoid heart disease. Am J Cardiol 2011;107:12211226.

79 Rorstad O: Prognostic indicators for carcinoid neuroendocrine tumors of the gastrointestinal tract. J Surg Oncol 2005;89:151-160.

80 Korse CM, Taal BG, de Groot CA, Bakker RH, Bonfrer JM: Chromogranin-A and N-terminal pro-brain natriuretic peptide: an excellent pair of biomarkers for diagnostics in patients with neuroendocrine tumor. J Clin Oncol 2009;27:4293-4299.

81 Nakagawa O, Ogawa Y, Itoh H, Suga S, Komatsu Y, Kishimoto I, Nishino K, Yoshimasa T, Nakao K: Rapid transcriptional activation and early mRNA turnover of brain natriuretic peptide in cardiocyte hypertrophy. Evidence for brain natriuretic peptide as an 'emergency' cardiac hormone against ventricular overload. J Clin Invest 1995;96:12801287.

82 Maeda K, Tsutamoto T, Wada A, Hisanaga T, Kinoshita M: Plasma brain natriuretic peptide as a biochemical marker of high left ventricular end-diastolic pressure in patients with symptomatic left ventricular dysfunction. Am Heart J 1998;135:825-832.

83 Bhattacharyya S, Toumpanakis C, Caplin ME, Davar J: Usefulness of N-terminal pro-brain natriuretic peptide as a biomarker of the presence of carcinoid heart disease. Am J Cardiol 2008;102:938-942.

84 Ramage JK, Ahmed A, Ardill J, Bax N, Breen DJ, Caplin ME, Corrie P, Davar J, Davies AH, Lewington V, Meyer T, Newell-Price J, Poston G, Reed N, Rockall A, Steward W, Thakker RV, Toubanakis C, Valle J, Verbeke C, Grossman AB: Guidelines for the management of gastroenteropancreatic neuroendocrine (including carcinoid) tumours (NETs). Gut 2012;61:6-32.

85 Lundin L, Oberg K, Landelius J, Hansson HE, Wilander E, Theodorsson E: Plasma atrial natriuretic peptide in carcinoid heart disease. Am J Cardiol 1989;63:969-972.

86 Bergestuen DS, Gravning J, Haugaa KH, Sahakyan LG, Aakhus S, Thiis-Evensen E, Oie E, Aukrust P, Attramadal H, Edvardsen T: Plasma CCN2/connective tissue growth factor is associated with right ventricular dysfunction in patients with neuroendocrine tumors. BMC Cancer 2010;10:6.

87 Bhattacharyya S, Toumpanakis C, Burke M Taylor AM, Caplin ME, Davar J: Features of carcinoid heart disease identified by 2 - and 3-dimensional echocardiography and cardiac MRI. Circ Cardiovasc Imaging 2010;3:103111

88 Howard RJ, Drobac M, Rider WD, Keane TJ, Finlayson J, Silver MD, Wigle ED, Rakowski $\mathrm{H}$ : Carcinoid heart disease: diagnosis by twodimensional echocardiography. Circulation 1982;66:1059-1065. 
89 Dobson R, Cuthbertson DJ, Jones J, Valle JW, Keevil B, Chadwick C, Poston GP, Burgess MI: Determination of the optimal echocardiographic scoring system to quantify carcinoid heart disease. Neuroendocrinology 2014;99:85-93.

90 Franzen D, Boldt A, Raute-Kreinsen U, Koerfer R, Erdmann E: Magnetic resonance imaging of carcinoid heart disease. Clin Cardiol 2009;32:E92-93.

91 Klobucic M, Paar MH, Padovan RS, Vincelj J, Fila B: New images in carcinoid heart disease. Cardiovasc J Afr 2012;23:e8-10.

92 Fiebrich HB, Brouwers AH, Links TP, de Vries EG: Images in cardiovascular medicine: myocardial metastases of carcinoid visualized by $18 \mathrm{~F}$-dihydroxy-phenyl-alanine positron emission tomography. Circulation 2008;118: 1602-1604.

93 Eriksson B, Kloppel G, Krenning E, Ahlman $\mathrm{H}$, Plockinger U, Wiedenmann B, Arnold R, Auernhammer C, Korner M, Rindi G, Wildi $S$ : Consensus guidelines for the management of patients with digestive neuroendocrine tumors - well-differentiated jejunal-ileal tumor/ carcinoma. Neuroendocrinology 2008;87:819.

94 Caplin M, Sundin A, Nillson O, Baum RP, Klose KJ, Kelestimur F, Plockinger U, Papotti M, Salazar R, Pascher A: ENETS Consensus Guidelines for the management of patients with digestive neuroendocrine neoplasms: colorectal neuroendocrine neoplasms. Neuroendocrinology 2012;95:88-97.

95 Pape UF, Perren A, Niederle B, Gross D, Gress T, Costa F, Arnold R, Denecke T, Plockinger U, Salazar R, Grossman A: ENETS Consensus Guidelines for the management of patients with neuroendocrine neoplasms from the jejuno-ileum and the appendix including goblet cell carcinomas. Neuroendocrinology 2012;95:135-156.

96 Plockinger U, Gustafsson B, Ivan D, Szpak W, Davar J: ENETS Consensus Guidelines for the Standards of Care in Neuroendocrine Tumors: echocardiography. Neuroendocrinology 2009;90:190-193.

97 Grozinsky-Glasberg S, Grossman AB, Korbonits M: The role of somatostatin analogues in the treatment of neuroendocrine tumours. Mol Cell Endocrinol 2008;286:238-250.
98 Rubin J, Ajani J, Schirmer W, Venook AP, Bukowski R, Pommier R, Saltz L, Dandona P, Anthony L: Octreotide acetate long-acting formulation versus open-label subcutaneous octreotide acetate in malignant carcinoid syndrome. J Clin Oncol 1999;17:600606.

99 Modlin IM, Latich I, Kidd M, Zikusoka M, Eick G: Therapeutic options for gastrointestinal carcinoids. Clin Gastroenterol Hepatol 2006;4:526-547.

100 Anderson AS, Krauss D, Lang R: Cardiovascular complications of malignant carcinoid disease. Am Heart J 1997;134:693-702.

101 Nishimura RA, Carabello BA, Faxon DP, Freed MD, Lytle BW, O'Gara PT, O'Rourke RA, Shah PM: ACC/AHA 2008 Guideline update on valvular heart disease: focused update on infective endocarditis: a report of the American College of Cardiology/American Heart Association Task Force on Practice Guidelines endorsed by the Society of Cardiovascular Anesthesiologists, Society for Cardiovascular Angiography and Interventions, and Society of Thoracic Surgeons. J Am Coll Cardiol 2008;52:676-685.

102 Marsh HM, Martin JK Jr, Kvols LK, Gracey DR, Warner MA, Warner ME, Moertel CG: Carcinoid crisis during anesthesia: successful treatment with a somatostatin analogue. Anesthesiology 1987;66:89-91.

103 Claure RE, Drover DD, Haddow GR, Esquivel CO, Angst MS: Orthotopic liver transplantation for carcinoid tumour metastatic to the liver: anesthetic management. Can J Anaesth 2000;47:334-337.

104 Castillo JG, Filsoufi F, Adams DH, Raikhelkar J, Zaku B, Fischer GW: Management of patients undergoing multivalvular surgery for carcinoid heart disease: the role of the anaesthetist. Br J Anaesth 2008;101:618-626.

105 Ockert DB, White RD: Anesthetic management of patients with carcinoid heart disease undergoing cardiac surgery: two case reports and a review of previous experience. J Cardiothorac Anesth 1988;2:658-665.

106 Kulke MH, O’Dorisio T, Phan A, Bergsland E, Law L, Banks P, Freiman J, Frazier K, Jackson J, Yao JC, Kvols L, Lapuerta P, Zambrowicz B, Fleming D, Sands A: Telotristat etiprate, a novel serotonin synthesis inhibitor, in patients with carcinoid syndrome and diarrhea not adequately controlled by octreotide. Endocr Relat Cancer 2014;21: 705-714.
107 Grant SC, Scarffe JH, Levy RD, Brooks NH Failure of balloon dilatation of the pulmonary valve in carcinoid pulmonary stenosis. Br Heart J 1992;67:450-453.

108 Hargreaves AD, Pringle SD, Boon NA: Successful balloon dilatation of the pulmonary valve in carcinoid heart disease. Int J Cardiol 1994;45:150-151.

109 Connolly HM, Nishimura RA, Smith HC, Pellikka PA, Mullany CJ, Kvols LK: Outcome of cardiac surgery for carcinoid heart disease. J Am Coll Cardiol 1995;25:410-416.

110 Connolly HM: Carcinoid heart disease: medical and surgical considerations. Cancer Control 2001;8:454-460.

111 Bhattacharyya S, Davar J, Dreyfus G, Caplin ME: Carcinoid heart disease. Circulation 2007;116:2860-2865.

112 Ridker PM, Schoen FJ: Surgical management of carcinoid heart disease. Ann Thorac Surg 1991;52:1208.

113 Ridker PM, Chertow GM, Karlson EW, Neish AS, Schoen FJ: Bioprosthetic tricuspid valve stenosis associated with extensive plaque deposition in carcinoid heart disease. Am Heart J 1991;121:1835-1838.

114 Ohri SK, Schofield JB, Hodgson H, Oakley $\mathrm{CM}, \mathrm{Keogh} \mathrm{BE}$ : Carcinoid heart disease: early failure of an allograft valve replacement. Ann Thorac Surg 1994;58:1161-1163.

115 McDonald ML, Nagorney DM, Connolly HM, Nishimura RA, Schaff HV: Carcinoid heart disease and carcinoid syndrome: successful surgical treatment. Ann Thorac Surg 1999;67:537-539.

116 Thorburn CW, Morgan JJ, Shanahan MX, Chang VP: Long-term results of tricuspid valve replacement and the problem of prosthetic valve thrombosis. Am J Cardiol 1983; 51:1128-1132.

117 Manoly I, McAnelly SL, Sriskandarajah S, McLaughlin KE: Prognosis of patients with carcinoid heart disease after valvular surgery. Interact Cardiovasc Thorac Surg 2014; 19:302-305.

118 Bhattacharyya S, Raja SG, Toumpanakis C, Caplin ME, Dreyfus GD, Davar J: Outcomes, risks and complications of cardiac surgery for carcinoid heart disease. Eur J Cardiothorac Surg 2011;40:168-172.

119 Boglioli LR, Gardiner J, Gerstenblith G, Taff ML, Cameron DE: Carcinoid heart disease with severe hypoxia due to interatrial shunt through patent foramen ovale. Tex Heart Inst J 1997;24:125-128. 